ters to drift can hardly fail to involve a continuance of present depreciated rates and perhaps a further decline. Occasionally, extreme declines will temporarily make possible the exportation of goods not regularly exported, but the general tendency will certainly be for both the export and the import business of Europe to fall away, re- flecting continued industrial and financial decay.

Depreciated exchange is not a corrective; it is merely a symptom of an unhealthy condition. It consequently does not subject producers in this country to abnormal foreign competition from which they might reasonably ask to be shielded by legislation.

\title{
The Part of Direct Exporting in the Future of American Industry
}

\author{
By Henry H. Morse \\ Chairman, Boston Export Round Table \\ and \\ Walter F. Wyman \\ Honorary Chairman, Boston Export Round Table
}

$\mathrm{T}_{\text {XPORT trade is the one adequate }}$ which owe their being to American brains and American labor. Those careful students of commerce whose vision has been so largely responsible for our domestic development are today found to be turning their eyes overseas. The law of diminishing returns is already curtailing the potential profits in many lines whose marketing has been confined within our boundaries. It is not necessary for a saturation point to be visible for it to exist. The fact that there is a definite saturation point which is only beyond the range of direct vision is the compelling force which is leading American industry into scientific direct exporting.

With the shortening distances due to improved methods of transportation; with the growing acceptance of higher standards of living; with the widening circle of demand for comfort, convenience and luxury as well as mere existence, the once limited field of many American industries has broadened to permit economical merchandising of
American product in foreign lands. In the rapid development of labor-saving machinery the possibilities of production have increased in mathematical progression in comparison to the increased consumer demand of the domestic market. The principles of mass merchandising as well as the principles of mass production are today understood, where two decades ago both were unknown. Due to the sudden demands of the World War, manufacturing capacity was increased overnight to a point far beyond the natural growth of several decades.

So we have on one hand a new consumer acceptance in foreign lands which is rapidly growing to definite consumer demand, not only for a widening variety of American-made merchandise but also for decidedly increased quantities of American-made merchandise. On the other hand, we have for the first time both the desire and the necessity for a wider market than even the increased population of the United States provides.

To a great extent the market beyond 
our boundaries is competitive only in a sense. There is a distinct division of manufactures in which American mechanical ingenuity and American insistence upon quality have both created new products and raised others to such a high standard as to involve a different classification from its prototype. The typewriter, the adding machine and agricultural machinery are typically American. Such prosaic articles as saws, paints and varnishes have been raised from mediocre articles that serve a purpose to products which have reached such standards of uniform high quality that they find a market abroad regardless of any price advantage that the foreign manufacturer may offer.

The two major divisions of export selling are direct exporting and indirect exporting. Indirect exporting is selling to a middleman, usually known as a commission house, having offices in this country and distributors abroad. The manufacturer sells to the commission house much as he would to a domestic customer. He is supplied by the commission house with full details as to marking, packing and invoicing each shipment. The manufacturer receives his pay from the commission house as he would from a domestic customer. He assumes no risks and takes no responsibility beyond delivery to the commission house or to the steamer designated by the commission house.

\section{Direct Exporting, Its Develop- MENTS aND ITs Services}

Direct exporting is the selling by a manufacturer to a customer resident abroad. In this case the manufacturer exercises his own judgment or obeys specific instructions received direct from the customer abroad in regard to packing, marking and invoicing. His merchandise is purchased without an intermediary by the customer abroad, to whom he looks for payment. Varying with his terms of sale, the manufacturer's responsibility ends at factory, at seaboard or at destination. There is no outstanding obstacle to prevent a manufacturer from combining both major selling methods. In fact, it is customary rather than the reverse for manufacturers to employ both direct and indirect exporting in the development of their overseas trade.

The most significant development which affects the future of American industry is the constantly growing attention manufacturers are giving, as a rule rather than the exception, to the direct exportation of their products to foreign markets. There are many reasons which underlie this development. The greatest reason is the broadened vision due to a greater necessity than existed a score of years ago. In 1900 the export trade of manufactures, particularly of branded merchandise, was entirely incidental and accidental to one group of American manufacturers. Serious direct exporting was confined to a handful of enterprises whose vision was nearly a generation in advance of that of the multitude. In 1900 the limitations of the domestic market did not exist for many new enterprises. In 1900 the overseas possibilities for volume business were unknown to many American manufacturers. In 1900 the foreign field was seriously regarded by the casual student of exporting merely as a dumping ground for surplus products, and its rightful place in American merchandising had not yet been understood. In 1900 our own great West was a market for products of our eastern factories instead of being, as at present, a competitive manufacturing district.

As a concrete illustration of the value of vision in merchandising, no 
more striking example can be portrayed than that involved in the solution of the problem of seasonal demand in the domestic market. The manufacturer of men's fancy hat bands, which are worn in the United States only during the summer months and on straw hats, is a typical example. His climatic problem which causes his seasonal problem is solved in the fact that when it is winter in the United States it is summer in Argentine Republic, and there is a year-around summer following the Equator. Another example of a different nature is that of the American toy manufacturer, whose domestic demand comes almost entirely in the late summer and early fall when the jobbers are stocking their Christmas goods. When the toy manufacturer develops a business in foreign lands he finds a market for his goods in the spring and early summer, because of the length of time that the goods are in transit and the willingness of the large foreign importer to take his goods early in order that he may be certain of them in time to redistribute among his local jobbers before the holiday season.

There is today a growing appreciation among consumers as well as by manufacturers that retail prices in the domestic market depend largely upon a volume of production adequate to tax factory capacity and to minimize the inevitable overhead charges of production, distribution and selling. Export trade obviously increases sales. Export trade obviously diminishes cost of production by absorbing overhead charges. Export trade, to the careful student, is known to have a lower selling cost per unit of merchandise because it customarily capitalizes existing brains, existing plant and the tremendous momentum which is part of a going business. Particularly in a seasonal business the return on fixed in- vestment is greatly increased because of the full time utilization of existing plant equipment, plant facilities and personnel. In addition, where seasonal demand would require the manufacture of fall goods in the early spring and storage of those goods through the summer, in order to maintain the manufacturing organization, an additional earning force is given to the capital invested through the manufacture of goods for foreign trade-goods which can be billed and become an asset instead of a liability as soon as manufactured.

It is common in such basic industries as shoes to adopt exactly this practice. Not only is use made of the plant in the off-season, but export orders are given preference and drafts are discounted following immediate shipment, thus supplying capital available for the purchase of raw materials for the seasonal domestic trade. In industries which involve the shipment of liquids in glass, there is a hiatus between fall and spring in which, because of danger of freezing, domestic shipments are extremely limited and confined to taking advantage of favorable weather conditions and of supplying domestic trade located near domestic branch warehouses. The shipping force in such factories is today kept intact and profitably employed in the packing, marking and shipping of export orders which can safely be hauled from warehouses located at seaboard to the warm holds of outgoing steamers.

This must not be taken as any defense of what in the best export circles is known as the unpardonable sin of "dumping." It is doubtful if a manufacturer is ever justified in selling his goods abroad at a price that is based on anything except cost of manufacture, plus cost of distribution, plus a reasonable profit. Occasionally a manufacturer may, for purely introductory 
sales purposes, feel himself justified in putting his goods in at a price that will later give him entrée into a market where the established price has been set by an inferior and long-established competitive article. Even in doing this the manufacturer must bear in mind the very great danger of finding this action subject to heavy legal penalties ranging from an increased rate of duty to permanent exclusion of his products from the market.

Direct exporting is an excellent selfdefense against foreign invasion of the domestic market. The American exporting manufacturer who has developed a world trade necessarily comes in contact with the American manufacturer who is selling his product in all the markets of the world, and is meeting in some one or more of those markets the most advanced competition in his particular line. When he has successfully solved the problem of meeting that competition, whether it be in Paris or Tokio, Abyssinia or Tasmania, he is prepared to forestall that competition before it reaches his domestic market. There is a further and great advantage in the rubbing of shoulders with the highest grade products of other manufacturing nations. Americans as a class are prone to consider that the United States alone can produce articles of transcendent merit. Naturally, this is in the face of our constant and long-established importations of French perfumes, Italian and Spanish oils, Panama hats, English cutlery and Parisian styles.

The consumer abroad has his choice of the masterpieces of the manufacturing world, and the American manufacturer, therefore, in the development of his export trade comes constantly in contact with the products of the best manufacturing brains of other nations. It is not uncommon for American manufacturers to improve their own prod- ucts best through the adoption or adaptation of products of whose very existence prior to their exporting they were in entire ignorance.

There is a still further and most important value directly to be credited to the practice of direct exporting. The customs tariffs of other political units often require most careful consideration in order that a popular retail price within these units may be possible. In the solution of these problems American manufacturers have found repeatedly that they could evolve a product which met the new cost requirements in such a manner as to result in a more attractive package. This saving in cost in order to meet a price requirement abroad is, therefore, an asset in a domestic market, since it results in a more attractive package at a lower cost of production. There are many minor manufacturing advantages which can be attributed to the practice of direct exporting. These vary with each market.

Entirely apart from the field of production is the field of trade practice and procedure. In this field, particularly in the defining of the maturity of obligations, our domestic practice is so markedly inferior to the prevailing practice in international commercial exchange that there is no fair basis for comparison. The great majority of American-manufactured products are sold on open account. This means that the goods are shipped in response to an order placed by mail or given to a salesman, and that the only definition of maturity date is that afforded by terms printed at the head of the invoice or described by the salesman. There is no formal acceptance of the goods and no written agreement to pay in accordance with the terms of sale. This is in distinct contrast to the documentary time draft procedure, which is the backbone of foreign commerce. 
In direct exporting it is the rule that all orders are signed at the time they are placed, and terms of sale form an integral part of any quotation. When the goods are shipped they are consigned to the order of the direct exporter, who sends through banking channels the negotiable bill of lading, insurance certificate and commercial invoice, with instructions that these documents, which are necessary for the securing of the goods by the customer abroad, are to be given to him upon his "acceptance" of the draft. This acceptance takes the form of the customer's endorsement of a draft which definitely states the date of maturity, and which equally definitely establishes the validity of the transaction and the acceptance of the terms of sale. The customer's debt then becomes one to the bank, which notifies him of its maturity. Failure to pay an accepted draft at maturity is analogous to an act of bankruptcy, and as such affects the standing of the importer in both local and international circles. From these two definitions it will be seen that the various and timid proposals in the domestic market tending toward the quasi establishment of a practice of trade acceptance are but the faltering step of an infant toward a goal definitely recognized.

\section{Value of Direct Exporting in} Periods of Depression

World-wide distribution established by direct exporting is the sole insurance of real value against times of domestic financial depression. It is practical business insurance to divide the risks of credit and depressions over the widest possible territory. Sane selection of foreign customers is based not on placing all foreign eggs in the basket of a single foreign market, but on distributing these in such cities as Yokohama, Shanghai, Hong Kong, Sydney, Mel- bourne, Bankok, Bombay, Cape Town, Rio Janeiro, Buenos Aires, Valparaiso, Lima, the capitals of Europe, such wonderful cities as Constantinople, Cairo and hosts of smaller but buying centers.

When a manufacturer has built up a clientele in foreign countries whose purchases form one-tenth of his total output his factor of safety is forty per cent greater than his non-exporting competitor because, following the customary practice of defining payment dates by drafts, he is sure of a sufficient volume of payments at anticipated times to tide over any temporary stringency in the domestic money market, whereas the very cause of the calling in of loans which makes it desirable for the non-exporter to make prompt collections will cause such customers to seek extensions. This factor of safety increases out of proportion as the percentage of exports is increased because, particularly on lines bearing a high profit, the manufacturer is able to meet his entire obligations at maturity from his proceeds on foreign orders, and could even close down his factories for a period of several months and make no attempt to enforce domestic payments due.

In fact, it is in a panic year that the direct exporting manufacturer reaps the greatest domestic advantages, for while his competitors are forced to conserve their resources he can conduct sales campaigns in every city they are forced to neglect. Where the non-exporter must offend slow-paying customers with imperative demands for settlement he, enjoying a steady influx of payments representing cost plus profit, is in a position not only to extend longer terms and to be lenient in collections, but also to solicit the patronage of the slow-paying but responsible buyers offended by competitors' collection methods. 
Not only is such a manufacturer's position of value to himself but it is also a decided benefit to his customers and his competitors' customers, for it enables the dealers constituting "the trade" as applied to his line to conduct business under normal business conditions and meet other more pressing obligations from their natural resources without forcing unfavorable loans or having their credit strained beyond its possibilities. Multiply the single exporting manufacturer by all his mates in all lines, and a veritable seawall is erected against the storm of financial stringency. Can there be a greater panacea for a panic caused by lack of money at home than a steady stream pouring in from abroad?

There is only harm in sales at bargain prices abroad when the domestic market is glutted, or in the dumping of obsolete and below-standard products on which no future is expected or possible; but in the carefully developed world-wide markets made possible by the superior quality of American-made goods backed by intelligent coöperation with foreign dealers and good service even in the height of domestic seasons, there is the one sure preventative of depressed financial conditions at home.

It should be known as an axiom that the nation whose manufacturers' products are sold in every corner of the world is panic-proof as against internal conditions. The best insuranceagainst a national panic is a healthy export trade.

\section{World-Wide Planning Essential FOR Exporting SucCess}

Well-balanced world-wide sales are never a matter of luck. The world is so large and its markets, large and small, are so many that only by careful planning is correct export development made possible.
There are fully thirty thousand manufacturing exporters in the United States, an estimate which checks with the official statistics and the investigations of export organizations. Not over seventy-five manufacturers-onequarter of one per cent-can rightfully claim adequate representation in even all the major markets of the world. Not over one hundred and fifty can prove that their export selling in both theory and practice is based upon plans laid years ahead.

This is a tremendous indictment. It charges American exporting with lack of forethought as well as lack of balanced export sales. Let us examine the facts - for it is facts and not opinion which are worth consideration.

Exporting is selling to the whole world. This truth must be accepted before progress is possible. Until a manufacturer is willing to think of selling abroad wherever a profit can be shown, he is certainly not entitled to be called an exporter, even if his ledgers show sales in Cuba and in China. A few scattered customers in foreign countries are no more a proof of exporting than a few freckles prove a man a Mongolian!

The outstanding error in American exporting lies in the beginner's usual question, "Where shall we first sell abroad?" The proper question is, "What method can we adopt which will logically bring about balanced export sales?" Exporting-modern scientific exporting - is far more than attempting to sell one market at a time sequenced in order of ease of securing sales. Such a method is exactly as absurd as for an enterprise which desired national distribution in the United States to work forward one state at a time, with no advance survey or preparation of the entire field.

There are many American manufacturers who are today enjoying a 
pleasing profit from export sales built up in crude ways. But these are the first to admit that their methods have robbed them of both earlier and larger profits and that today their export distribution is still "spotty" and without correct balance. The mere fact that many are profiting by export trade is no proof that greater profits should not have been made, and that future efforts will not be decidedly handicapped by the hit-or-miss methods that forgot the future by too close a focus on the present.

The world is large. Therefore, the first step of the prospective exporter should be to admit that he has before him a task worthy of his best brains and demanding the most careful and skilled planning. Before active export selling starts, there should be a world plan which is based on a knowledge of the world and its markets and a vision of a decade in advance. It is costly to ignore this concept of exporting. Countless American manufacturers have, by ignoring this basic foundation, entered into agency relations that within a few years proved to block their future, not alone in the particular countries in which they appointed agents, but in entire continents.

One illustration will drive home this important point. A New York manufacturer of paints, because he had no plan covering his export future, gave the agency for one of his products to an agent in Rio Janeiro; the agency for all of his products for Argentina to a representative in Buenos Aires; the Chilian agency for a paint remover to a wholesaler and retailer in Valparaiso, and the agency for varnishes to a retailer in Lima. Contracts prohibited the paint manufacturer from selling other than the agents.

What was the result? The paint manufacturer, by giving the exclusive agency for his automobile paints to a dealer in Rio Janeiro for a term of ten years, found himself two years later unable to interest the one most desirable agency connection in Rio Janeiro. This corporation in Rio Janeiro refused, naturally, to divide the agency with a small and little-known dealer in its own city. In other countries the same general result came from the same general cause-blocked efforts due to failure to plan. The agencies granted made it impossible to send a traveler profitably, since the traveler could only have visited to advantage Uruguay, Paraguay, Bolivia and Ecuador, due to the agencies and the conditions under which they were conducted. In a sentence, it can be said that by failure to plan, the paint maker set back his sound development in South America by at least twenty years.

Even students of exporting have all too often failed to grasp the situation. One instructor in foreign trade in a most important eastern university taught his students the theory of exporting based on selling effort confined to the easiest market-the one in which at the moment general conditions were most favorable. This doctrine of expediency - interesting and simple as it may sound-is an infallible recipe for later regrets! The prospective exporter who is afraid to face the fact that this is a large world or who is unable or unwilling to give adequate time to advance planning for his commercial conquest of it had best remain confined to domestic selling!

There is a vast difference between advance planning for an ultimate world-wide and balanced trade and an attempt to conduct an intensive worldwide selling campaign from the very start. Only enterprises with exceptional financial resources can attempt wisely any foreign trade effort which involves the simultaneous attack on a large number of markets before the 
working capital is earned by a more modest entry into exporting. Conversely, it is entirely possible for any manufacturer, adequately financed for domestic trade, to plan correctly for ultimate world-wide trade and to proceed step by step, directly toward his goal.

\title{
The Probable Future Development of Grain Trade of the United States
}

\author{
By Julius H. Barnes \\ Barnes-Ames Company, Duluth
}

$\mathrm{W}^{\mathrm{s}}$ AR'S influence is clearly shown in a study of the food supply of Europe during war-years. The change wrought in sources of overseas supply rises strikingly above all other phenomena and centers in the expansion of food production in America and the clear deflection of ordinary ocean trade currents in the products of the farm. For example, there is in a study of crop production, marketing and movement, as influenced by the necessities of warring countries, a clear indication that price inducement is the governing factor most apparent in America's farm yields.

Prior to the war there was a general acceptance that in America there were two distinct trends in grain production:

1. The elimination of our export grain surplus by the growing necessities of a home population.

2. The reduction in total grain yields by the replacement of diversified farming.

We are now able to see, by the actual response of American farms to the price inducement which war's higher levels created, that both the area of grain production and the yield per acre were possible of material enlargement. This trend is most clearly shown by a grouping of the years' production, for the purpose of ready comparison.

The four years prior to the world war recorded an average grain production of the United States, as follows:

Bread grains (Wheat and Rye)

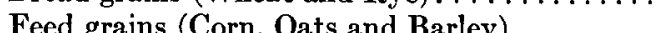

Total grain production ( 5 chief crops)

The five war years averaged in grain production as follows:

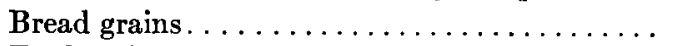

Feed grains

8.6 bushels per capita

Total grain production ( 5 chief crops).
7.8 bushels per capita $40.32 "$ " "

$47.4 \quad \cdots \infty \cdots$

With ocean commerce freed of the submarine menace, but production still under the influence of war grain prices, the crop of 1919 recorded a yield of:

Bread grains

Feed grains.

Total grain production ( 5 chief crops)
9.77 bushels per capita

40.93 